so much less chance is given them of placing their men in suitable employment. The oil industry, he declared, may learn too late its need of research. Oil is now so readily available that restriction, in the interests of commercialism, has to be placed on its production. The processes are wasteful and uneconomic, but "no one seems to mind so long as dividends are maintained". Yet petroleum can be made the source of a vast number of chemical products of service to man. Finally, Prof. Thorpe characterised as a "disastrous tendency" the results which accrue from the neglect, or even refusal, of directors of companies dealing with industries based on scientific methods to place on their boards men of scientific experience and capacity. We have seen the light; but do we not now seem to be reverting to type?

\section{Public Television in Germany}

THE Minister of Posts, Herr Eltz von Rubenach, opened on March 1 the German Post Office's two. way telephone-television service connecting Berlin and Leipzig, a distance of about 100 miles, by cable. According to The Times of March 2, the Minister afterwards saw and spoke to the Chief Burgomaster of Leipzig. This is the first service of the kind in the world and it will remain open during the Leipzig Spring Fair, which ends on March 7 ; it will then be closed until March 30 for testing purposes. At present, seeing by telephone in Germany is limited to persons who go to public offices, two of which have been opened in each town. A three minute communication costs 3 marks 50 pfennigs. This includes the notification of a specified person in the town at the other end of the line. Great public interest has been aroused, the bookings for last Monday being all taken up by 6 p.m. on Sunday. The quality of the pictures produced appears to be good, 180-line definition and 25 frames a second being used. The head and shoulder image of a person is clearly produced. The effect is comparable to a small size projection of a substandard cinema film. The cabins are fitted with comfortable armchairs; the user rests his head on a cushion and the attendant lowers or raises the chair until it is exactly in focus with the scanning apparatus. The image of the correspondent appears above the bright light of the scanner, but is not disturbed by it. Details like the bands of a wrist-watch or a ring on the hand holding the telephone are said to be clearly visible. The apparatus used in Berlin was constructed by the German P.O. laboratory and that used in Leipzig by the Fernseh-Aktiengesellschaft, of which Baird Television Ltd. holds a quarter of the shares.

\section{X-Ray Studies of Molecular Structure}

ThE thirty-third Bedson Lecture was delivered on February 21 at Armstrong College, Newcastle-onTyne, by J. D. Bernal, assistant director of research in the Crystallographic Laboratory, Cambridge, who took as his subject "Modern Crystallography and Organic Chemistry". Mr. Bernal gave practical details of the method of X-ray examination of organic substances, which he explained constitutes an indirect method of seeing molecular structures. A pencil of X-rays is diffracted by all possible internal planes of regularity of a crystal to a series of points which can be photographed; the intensities and angles of deviation of these diffracted rays constitute the observed data which will unequivocally characterise a substance. It is also relatively easy to determine the symmetry of the molecule, which in some cases identifies an isomeride as cis or trans, and to determine the size of the unit cell of the crystal from which, knowing the density, the molecular weight can be found, and also the shape of the molecule, which has been of value in sterol chemistry. The complete interpretation of $\mathrm{X}$-ray diagrams to yield the position of each atom in the unit cell and the electron density in each part of the molecule is much more laborious and has only recently been achieved. Besides confirming the classical organio structures, this method gives direct information of the distortion of valency angles in such cases as durene, and of the semi-aromatic nature of the bonds in benzoquinone and dinitrobenzene.

\section{Maori Culture and Modern Civilisation}

Lord Bledisloe's eloquent appeal on behalf of the Maoris in his address to the Royal Society of Arts on February 27 came with added force from one who both by his official and his personal acts during the five years of his tenure of the Governor-Generalship of New Zealand had shown that not only had he a sympathetic appreciation of the history of the race and its achievement in the past, but also that he believed in the potentialities of this people as an element in the future cultural development of the Dominion. In characterising them as the most interesting, the most attractive and the most civilisable of the 'native' peoples of the world, he did not go beyond the warrant of the results of scientific study of the Maori during the last generation or more. When he reviewed the relations of white administration and the natives from the days of early colonisation down to recent times, Lord Bledisloe displayed sound judgement in attributing the decadence of the race, which at one time seemed in danger of extinction, to the harsh and inequitable land policy of the Government, which confiscated and alienated native holdings after the Maori wars. Experience elsewhere, notably in South Africa and North America, has shown that the well-being of an indigenous people is closely bound up with an understanding on the part of the administration of the place of land-tenure in its cultural economy. The remarkable recovery of the Maoris during the last generation, to which Lord Bledisloe referred, is in itself a sufficient guarantee that if the present moment is, as he describes it, a crisis in their history, they will repay the confidence which he trusts will be reposed in them, should their future be assured them and their equality of status under British sovereignty be unchallenged in four years time, when New Zealand will celebrate her centenary as a British possession. 